\title{
Bioefficacy of IPM Modules for the Management of Aphid, Lipaphis erysimi Kalt. Infesting Mustard in Rajasthan
}

\author{
D.K. Jain ${ }^{1 *}$, R.K. Gangwar ${ }^{2 \#}$, Hemant Swami ${ }^{3}$ and H.K. Sumeriya ${ }^{3}$ \\ ${ }^{1}$ SMS, Plant Protection, KVK, Badgaon, Udaipur, Rajasthan-313 011 \\ ${ }^{2}$ SMS, Plant Protection, KVK, Chomu, Jaipur, Rajasthan -303 702 \\ ${ }^{3}$ RCA, MPUAT, Udaipur, Rajasthan-313002
}

*Corresponding author

\section{Keywords \\ Bio-pesticides, Management, IPM modules, Mustard aphid}

\section{Article Info}

Accepted:

26 May 2020

Available Online:

10 June 2020

\section{A B S T R A C T}

The field Experiments was conducted at Dabok village, block- Mavli, District, Udaipur, Rajasthan, during 2016-17 on Indian mustard (Brassica juncea) variety NRCDR-2. Eight treatments including untreated control plot were evaluated in randomized block design with three replications. Different modules which consist of either both biopesticides or both insecticide or one biopesticides and another is insecticide were evaluated against mustard aphid Lipaphis erysimi (Kaltenbach), the results revealed that all the treatments were found significantly effective at different time intervals at each spray in reducing the infestation of Mustard aphid, L. erysimi and thus increasing the yield significantly as compared to untreated control plots. The mean of initial mustard aphid population were found on top $10 \mathrm{~cm}$ apical twigs/plot ranged from 105.82 to 108.28 aphids before the spray and did not differ significantly The module 4 consisting of first spray with imidacloprid 17.8 SL @ 20g a.i./ha. and second also with imidacloprid 17.8 SL @ 20g a.i./ha. was found most effective treatment with minimum number of aphids and it was significantly superior over rest of the treatments. It is followed with the module 2 consist of first spray with acetamiprid $20 \%$ SP @ $0.037 \%$ and second also with acetamiprid $20 \%$ SP @ $0.037 \%$ ) and module 7 consist of first spray with dimethoate 30EC @ 300g a.i./ha and second sparay with dimethoate 30EC @ 300g a.i./ha (1 lit/ha.) was found most effective treatment in reducing the aphids population. The highest yield (16.03 q/ha) with high cost benefit ratio (1:9.64) was also recorded in module 4 consisting of first spray with imidacloprid 17.8 SL@ 20g a.i./ha. and second also with imidacloprid 17.8 SL @ 20g a.i./ha.

\section{Introduction}

Mustard, Brassica juncea (Linn.), the major edible oilseed brassica crop, constitutes a major source of edible oil for the human consumption in India and has assumed significance in the national economy by occupying 2nd ranks in acreage next to groundnut and 3rd in world's production of oilseeds. Mustard is the second largest produced oilseed in the world with an area of $37.0 \mathrm{~m} \mathrm{ha}^{-1}$, with the production of $63.09 \mathrm{~m}$ 
tones and the productivity of $18.50 \mathrm{q} \mathrm{ha}^{-1}$. In India it had the area of $6.3 \mathrm{~m} \mathrm{ha}^{-1}$, with production of $7.37 \mathrm{~m}$ tones and productivity of $11.90 \mathrm{q} \mathrm{ha}^{-1}$. India contributing 28.3 per cent and 19.8 per cent in the world acreage and production. India produced around $7.4 \mathrm{mt}$ of rapeseed-mustard next to China (11.12 mt) (Anon., 2014). Rajasthan contributes $45.5 \%$ area and $48.6 \%$ production to the nation. Zone III b of Rajasthan state is known as mustard bowl has higher productivity (15.78 q/ha) as compared to nation (11.9 q/ha). During Rabi 2009-10 mustard was grown in about 7.70 lakh hectare and the average productivity was 15.78q/ha (AICRP, 2009). In India, major mustard and rapeseed producing States are Uttar Pradesh, Rajasthan, Madhya Pradesh, Haryana, Gujarat, Assam, West Bengal and Punjab. Mustard crop suffers heavily from insect pests and diseases right from germination to harvesting. According to Sachan and Purwar (2007) mustard is attacked by more than 43 insect species viz., mustard aphid, Lipaphis erysimi; mustard sawfly, Athalia proxima; painted bug, Bagrada cruciferum; leaf minor, Chromatomyia herticola and Bihar hairy caterpillar, Spilarctia oblique. Among them, mustard aphid is the most destructive pest, which causes 35.4 to 73.3 per cent yield loss, 30.09per cent seed weight loss and 2.75 per cent oil loss (Bakhetia and Sekhon, 1989; Singh and Premchand, 1995; Sharma and Kashyap, 1998), even 97.4 per cent yield loss reported by Patel et al., (2004). Nymph and adult of aphids, suck the cell sap from inflorescence, terminal twig, pods, leaves and branches which causes higher loss. Severe infestation leads to poor pod formation, curling shriveling of leaves and drying of plant. On the other hand, aphids secrete honeydew, which facilitates the growth of black sooty mold that makes the leaves appear dirty black. The cloudy and cold weather $\left(20^{\circ} \mathrm{C}\right.$ or below) with high relative humidity $(70-75 \%)$ are very favourable condition for the multiplication (Awasti, 2002). Several approaches have been adapted to manage insect-pests on mustard crop, among these methods of pest control, chemical control have largely been used for the control of insect-pests. Many unwanted side effects of older insecticides such as residue problem, environmental hazards, destruction of nontargeted insects such as parasites and predators as bio-control agents and honeybees as pollinators and development of resistance in insect to insecticides etc. So there is a need to use the chemicals and bio-pesticides for control ofthe mustard aphid. Therefore present investigation was carried out.

\section{Materials and Methods}

The field Experiments was conducted at Dabok village, block Mavli, District Udaipur, Rajasthan, during 2016-17 on Indian mustard (Brassica juncea) variety NRCDR-2. Eight treatments including untreated control plot were evaluated in RBD (Randomized Block Design) with three replications. Different modules which consist of either both biopesticides or both insecticide or one biopesticides and another is insecticide were evaluated (Table-1) using manually operated knapsack sprayer having duromist nozzle to sprays. In each module, two foliar sprays were given, First spray was given forty days after sowing of crop (Based on ETL- 25 aphids $/ 10 \mathrm{~cm}$ apical shoot or central twig) and second spray was given fifteen days after first spray. Population of aphids was counted on the 10 randomly selected plants/plot from top $10 \mathrm{~cm}$ apical shoot (twigs) with the help of magnifying hand lens at 1 day prior to spraying and $3,7 \& 10$ days after spraying. The yield of seed from each plot was weighed separately. Data were complied and analyzed statistically. Incremental cost benefit ratio (ICBR) for each treatment was calculated by dividing net gain over control by total cost of plant protection. Finally, net ICBR for each 
treatment was evaluated by dividing net profit by total cost of plant protection measure.

\section{Results and Discussion}

Each treatment or modules was applied two times during the crop season. First spraying was done when the crop was 40 days (Based on ETL- 25 aphids $/ 10 \mathrm{~cm}$ apical shoot or central twig) and second spray was given 15 days after first spray. Population of aphids was counted on the 10 randomly selected plants/plot from top $10 \mathrm{~cm}$ apical shoot (twigs) with the help of magnifying hand lens at 1 day prior to spraying and 3, $7 \& 10$ days after spraying. Observation of aphids/plant was recorded after first and second spray of different treatments.

\section{First spray}

The mean number of aphids/plant has showed in Table 2. The results revealed that all the treatments were significantly effective in reducing the infestation of Mustard aphid, $L$. erysimi and thus increasing the yield significantly as compared to untreated control plots. The initial mustard aphid population ranged from 105.82 to 108.28 aphids before the spray and did not differ significantly. Data recorded on $3^{\text {rd }}$ day after first spray application, aphid population was decreased in every treatment except control plot. The module or treatment $\left(\mathrm{T}_{4}\right)$ consisting of first spray with imidacloprid 17.8SL @ 20g a.i./ha, proved most effective treatment with minimum number of aphids (18.64 aphids) and it was significantly superior over rest of the treatments. It is at par with the module or treatment $\left(\mathrm{T}_{2}\right)$ consist of first spray with acetamiprid 20 \% SP @ 0.037\%, (21.39 aphids) and module or treatment $\left(\mathrm{T}_{7}\right)$ consist of first spray with dimethoate 30EC @ 300g a.i./ha (22.74 aphids). The next in order of effectiveness was the module or treatment (T6) consist of first spray with Beauveria bassiana CFU $1 \times 10^{8} @ 2.0 \quad \mathrm{~kg} / \mathrm{ha} \quad(35.38$ aphids).Module or treatment $\left(\mathrm{T}_{5}, \mathrm{~T}_{3}\right.$ and $\left.\mathrm{T}_{1}\right)$ consist of first spray with azadirachtin 1500 ppm @ $1.5 \mathrm{ml} / \mathrm{lit}$ gave the same results because same biopesticide is used in same concentration means, in these treatments, aphids population was 54.07,54.38 and 54.49 respectively. A maximum aphid (134.31 aphids) was recorded in control plot. Data recorded on $7^{\text {th }}$ day after spraying, showed decrease of aphids populations in all treatments except in control plot. The minimum number of aphids (14.91 aphids) was recorded in the plot (module or treatment $\left(\mathrm{T}_{4}\right)$ treated with Imidacloprid 17.8SL @ 20g a.i./ha,it was significantly superior to rest of treatments. The module or treatment $\left(\mathrm{T}_{2}\right)$ consisting of first spray with Acetamiprid 20 \% SP@0.037\%, (19.80 aphids) and module or treatment $\left(\mathrm{T}_{7}\right)$ consisting of first spray with dimethoate 30EC @ 300g a.i./ha (22.51 aphids) are respectively, at par with module or treatment $\left(\mathrm{T}_{7}\right)$. It is followed by treatment $\left(\mathrm{T}_{6}\right)$ consisting of first spray with Beauveria bassiana CFU $1 \times 10^{8} @ 2.0 \quad \mathrm{~kg} / \mathrm{ha} \quad(34.02$ aphids).Rest of the treatments gave quite similar results of decrease in aphid's population because in all three treatments first spray was done with azadirachtin 1500 ppm @ $1.5 \mathrm{ml} / \mathrm{lit}$. Maximum aphids 147.58 were recorded in control plot. On the $10^{\text {th }}$ day after spray also showed decreased pattern of aphids in all treatments except control plot. The minimum aphid population (12.02 aphids) recorded in the module or treatment $\left(\mathrm{T}_{4}\right)$ consisting of first spray with imidacloprid 17.8SL@20g a.i./ha, and it was superior over rest of the treatments. It is at par with the module or treatment $\left(\mathrm{T}_{2}\right)$ consist of first spray with acetamiprid 20\% SP @ 0.037\%, (15.88 aphids) and module or treatment $\left(\mathrm{T}_{7}\right)$ consist of first spray with dimethoate 30EC @ 300g a.i./ha (20.88 aphids). The next in order of effectiveness was the module or treatment $\left(\mathrm{T}_{6}\right)$ consist of first spray with Beauveria

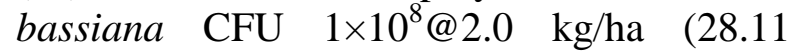


aphids). Module or treatment $\left(\mathrm{T}_{1}, \mathrm{~T}_{5}\right.$ and $\left.\mathrm{T}_{3}\right)$ consist of first spray with azadirachtin 1500 ppm @ $1.5 \mathrm{ml} /$ lit gave the near about same results because same biopesticide is used in same concentration means, in these treatments, aphids population was 36.08,36.70 and 36.79 respectively. A maximum aphid (162.17 aphids) was recorded in control plot (Fig. 1).

\section{Second spray}

The second spraying was done 15 days after first application and data recorded on the incidence of L. erysimi (Table 2). A similar trend of efficacy of treatments as in first application on reduction of aphids was recorded in module $\left(\mathrm{T}_{4}\right)$, module $\left(\mathrm{T}_{2}\right)$, module $\left(\mathrm{T}_{7}\right)$, module $\left(\mathrm{T}_{5}\right)$ and module $\left(\mathrm{T}_{6}\right)$ after the second spray but its quite change in other modules i.e., module $\left(\mathrm{T}_{1}\right)$ and module $\left(\mathrm{T}_{3}\right)$. Observations recorded on $3^{\text {rd }}$ day after second application showed that all the treatments were found effective over control (Table 2). The aphid population ranges were foundfrom 9.44 to 32.97 aphids/plant. The minimum population (9.44 aphids/plant) was recorded from module or treatment $\left(\mathrm{T}_{4}\right)$ consist of second spray with imidacloprid 17.8SL@20g a.i./ha. It was followed by module or treatment $\left(\mathrm{T}_{2}\right)$ consist of secondspray with acetamiprid 20\% SP @0.037\%, (12.88 aphids) and module or treatment $\left(\mathrm{T}_{7}\right)$ consist of second spray with dimethoate 30EC @ 300g a.i./ha (14.12 aphids). Less effective in comparison of imidacloprid 17.8SL @ 20g a.i./ha were, module or treatment $\left(\mathrm{T}_{6}\right)$ consist of Beauveria bassiana $\left(1 \times 10^{8} \mathrm{CFU}\right) @ 2 \mathrm{~kg} / \mathrm{ha}(23.28$ aphids/plant)and module or treatment $\left(\mathrm{T}_{1}\right)$ consist of second spray with acetamiprid 20\% SP @ $0.037 \%$ next to follow in order with aphid population (24.13 aphids) also followed by module or treatment $\left(\mathrm{T}_{3}\right)$ consist of second spray with imidacloprid 17.8SL @ 20g a.i./ha with aphid population (26.14 aphids).Module or treatment $\left(\mathrm{T}_{5}\right)$ consist of second spray with azadirachtin 1500 ppm @ $1.5 \mathrm{ml} / \mathrm{lit}$ is the very less effective with aphid population (32.97 aphids/plant). Maximum population (168.11 aphids/plant) was recorded in untreated control plot. At seventh days the aphid populations were decreased slightly were found 2.79 to 26.76 aphids/plant. The minimum population (2.79 aphids/plant) was recorded from module or treatment $\left(\mathrm{T}_{4}\right)$ consist of second spray with imidacloprid 17.8SL@20g a.i./ha. It was followed by module or treatment $\left(\mathrm{T}_{2}\right)$ consist of secondspray with acetamiprid 20\% SP @ $0.037 \%$, (6.17 aphids) andat par with module or treatment $\left(\mathrm{T}_{7}\right)$ consist of second spray with dimethoate 30EC @ 300g a.i./ha (7.29 aphids). The next in order of effectiveness was the module or treatment $\left(\mathrm{T}_{3}\right)$ consist of second spray with imidacloprid 17.8SL @ $20 \mathrm{~g}$ a.i./ha with aphid population (13.18 aphids) which is at par with module or treatment $\left(\mathrm{T}_{1}\right)$ consist of second spray with acetamiprid $20 \%$ SP @ $0.037 \%$ with aphid population (14.26 aphids) similar to module or treatment (T6) consist of second spray with Beauveria bassiana CFU $1 \times 10^{8} @ 2.0 \mathrm{~kg} / \mathrm{ha}$ (16.77 aphids) Beauveria bassiana (1×10 $\left.{ }^{8} \mathrm{CFU}\right) @ 2 \mathrm{~kg} / \mathrm{ha}$ (16.67 aphids/plant). Module or treatment $\left(\mathrm{T}_{5}\right)$ consists of second spray with azadirachtin 1500 ppm @ 1.5 $\mathrm{ml} /$ lit is the very less effective with aphid population (26.76 aphids/plant). Maximum population (178.32 aphids/plant) was recorded in untreated control plots.

Observation on $10^{\text {th }}$ days the minimum population (0 aphids/plant) was recorded from module or treatment $\left(\mathrm{T}_{4}\right)$ consist of second spray with imidacloprid 17.8SL @ 20g a.i./ha. It was followed by module or treatment $\left(\mathrm{T}_{2}\right)$ consist of secondspray with acetamiprid $20 \%$ SP @ $0.037 \%$, (0.88 aphids), module or treatment $\left(\mathrm{T}_{7}\right)$ consist of second spray with dimethoate 30EC @ 300g a.i./ha (3.16 aphids), module or treatment $\left(\mathrm{T}_{3}\right)$ consist of 
second spray with imidacloprid 17.8SL@ $20 \mathrm{~g}$ a.i./ha with aphid population (5.78 aphids) which is at par with module or treatment (T1) consist of second spray with acetamiprid $20 \%$ SP @ $0.037 \%$ with aphid population (6.28 aphids) similar to module or treatment $\left(\mathrm{T}_{6}\right)$ consist of second spray with Beauveria bassiana CFU $1 \times 10^{8} @ 2.0 \mathrm{~kg} / \mathrm{ha}$ (10.89 aphids) Beauveria bassiana $\left(1 \times 10^{8} \mathrm{CFU}\right) @ 2 \mathrm{~kg} / \mathrm{ha}$ (16.67 aphids/plant). Module or treatment $\left(\mathrm{T}_{5}\right)$ consists of second spray with azadirachtin 1500 ppm @ 1.5 $\mathrm{ml} /$ lit is the very less effective with aphid population (18.28 aphids/plant). Maximum population (211.89 aphids/plant) were recorded in untreated control plots.. The evident from above findings that all the treatments were effective in reducing population at different intervals after each spray in comparison to untreated control. The Module or treatment consisting of both first and second spray with imidacloprid 17.8SL @ 20g a.i./ha, acetamiprid $20 \%$ SP @ $0.037 \%$ and dimethoate 30EC @ 300g a.i./ha were proved most effective treatment for the control of mustard aphid in present investigation.

The effectiveness of imidacloprid 17.8 SL @ $20 \mathrm{~g}$ a.i./ha and acetamiprid 20\% SP @ 0.037\% for the control of $L$. erysimi has also been reported by Dhaka et al., (2009); Bhati and Sharma (2014). Meena et al., (2013) used eight microbial and bio-products against mustard aphid in which they have proved that Beauveria bassiana $1 \times 10^{8} \mathrm{CFU} @ 2 \mathrm{ka} / \mathrm{ha}$ and neem seed kernel extracts were significantly best to the control plot. These findings are in agreement with the results obtained by Gour and Pareek (2003) and Choudhury and Pal (2005). The efficacy of imidacloprid is also reportedby several workers viz., Kumar et al., (2007), Rana et al., (2007), Singh and Verma (2008) and Bapari et al., (2008). Dimethoate 30 EC @ $1000 \mathrm{ml} . / \mathrm{ha}$ and Azadirachtin was recorded effective in reducing aphid population in the present studies which is conformity with the findings of earlier studies conducted by Islam et al., (1990), Sinha et al., (1997), Gazi et al., (2001), Choudhury and Pal (2005), Bapari et al., (2008), Khedkar et al., (2012)and Bhati and Sharma (2014) (Fig. 2).

\section{Effect of insecticides modules on seed yield of mustard}

The effectiveness of all modules to manage mustard aphid, Lipaphis erysimi (Kaltenbach) was also determined on the basis of seed yield (Table-3). All the treated plots resulted significantly higher yield in comparison to untreated control plot $(7.88 \mathrm{q} / \mathrm{ha})$, ranging between 8.97 to $16.03 \mathrm{q} / \mathrm{ha}$. The maximum yield was obtained with module 4 , consisting of first spray with imidacloprid 17.8SL @ 20g a.i./ha and second also with imidacloprid 17.8SL @ 20g a.i./ha $(150 \mathrm{ml} / \mathrm{ha})$ giving $16.03 \mathrm{q} / \mathrm{ha}$ and was found superior over rest of all other treatments. The Module 2 ,consisting of first spray with acetamiprid 20\% SP @ $0.037 \%$ second also with acetamiprid 20\% SP @ 0.037\% second most effective treatment with yield of $14.88 \mathrm{q} / \mathrm{ha}$ followed by module 7 , consisting of first spray with dimethoate 30EC @ 300g a.i./ha and second also with dimethoate 30EC @ $300 \mathrm{~g}$ a.i./ha (1 lit/ha), Module 3, first spray with Azadirachtin 1500 ppm @ @ 1.5 ml/lit. Second with Imidacloprid 17.8SL @ 20g a.i./ha, Module 1, first spray with Azadirachtin 1500 ppm @ $1.5 \mathrm{ml} /$ lit. second with acetamiprid 20\% SP @0.037\% and module 6, first spray with Beauveria bassiana CFU $1 \times 10^{8} @ 2.0 \mathrm{~kg} / \mathrm{has}$ second also with Beauveria bassiana CFU 1×108@2.0 kg/ ha with the yield of 13.21, 12.17, 11.47 and $10.78 \mathrm{q} / \mathrm{ha}$, respectively. Among the different treatments lowest yield $(8.97 \mathrm{q} / \mathrm{ha})$ was found in case of Module 5, first spray with azadirachtin 1500 ppm @ $1.5 \mathrm{ml} /$ lit second also with azadirachtin 1500 ppm@1.5 ml/lit. 
Increase in yield over control varied from 1.09 to $8.15 \mathrm{q} / \mathrm{ha}$ in different treatments. Maximum increase in yield $(8.15 \mathrm{q} / \mathrm{ha})$ was recorded in Module 4,consisting of imidacloprid 17.8SL @ 20g a.i./haimidacloprid 17.8SL @ 20g a.i./ha (150 ml /ha) followed by module 2,consisting of acetamiprid $20 \%$ SP @ 0.037\%-Acetamiprid $20 \%$ SP @ 0.037\%,Module 7,consisting of dimethoate 30EC @ 300g a.i./ha- Dimethoate 30EC @ 300g a.i./ha (1 lit/ha), Module 3, consisting of azadirachtin 1500 ppm @ @ 1.5 ml/lit.- imidacloprid 17.8SL @ 20g a.i./ha, Module 1, consisting ofAzadirachtin 1500 ppm @ 1.5 ml/lit.- acetamiprid 20\% SP $@ 0.037 \%$ and module 6,consisting of Beauveria bassiana CFU 1×10 $@ 2.0$ kg/haBeauveria bassiana CFU $1 \times 10^{8} @ 2.0$ $\mathrm{kg} / \mathrm{ha}$,in which increase in yield were 7.00, 5.33, 3.59, and 2.90q/ha respectively. However, lowest increase in yield 1.09 q/ha was recorded in plot treated with Module 5,consisting of azadirachtin 1500 ppm @ 1.5 ml/lit - azadirachtin 1500 ppm @ 1.5 ml/lit.

Perusal of table 3 indicates that maximum gain in net income of Rs. 25845/ha was found from Module 4, consisting of imidacloprid 17.8SL@ 20g a.i./ha- imidacloprid 17.8SL @ $20 \mathrm{~g}$ a.i./ha(150 $\mathrm{ml} / \mathrm{ha})$ treated plot followed by Module 2,consisting of acetamiprid 20\% SP @ 0.037\%- acetamiprid 20\% SP @ $0.037 \%$, Module 7,consisting of dimethoate 30EC @300g a.i./ha- dimethoate 30EC @ $300 \mathrm{~g}$ a.i./ha (1 lit/ha) with net profit of Rs. 21370, 15755/ha, respectively. The minimum net profit (Rs. 2695/ha) was obtained from module 5,consisting of azadirachtin 1500 ppm @ $1.5 \mathrm{ml} / \mathrm{lit}$ - azadirachtin 1500 ppm@ 1.5 $\mathrm{ml} / \mathrm{lit}$. Cost benefit ratio of the treatments showed that module 4, consisting of imidacloprid 17.8SL @ 20g a.i./haImidacloprid 17.8SL @ 20g a.i./ha(150 ml /ha)ranked first indicating the maximum B:C Ratio (1: 9.64) followed by Module 2,consisting of acetamiprid 20\% SP @ $0.037 \%$ - acetamiprid 20\% SP @ 0.037\% with B:C Ratio (1:6.83), it is just at par with Module 6,consisting of, Beauveria bassiana CFU 1×108 @2.0 kg/ha-Beauveria bassiana CFU $1 \times 10^{8} @ 2.0 \mathrm{~kg} / \mathrm{ha}$ with B:C Ratio (1:6.52) and Module 3,consisting of azadirachtin $1500 \mathrm{ppm}$ @ $1.5 \mathrm{ml} / \mathrm{lit}$.imidacloprid 17.8SL @ 20g a.i./ha with B:C Ratio (1:5.98 and Module 7, consisting of dimethoate 30EC @ 300g a.i./ha- dimethoate 30 EC @ 300g a.i./ha (1 lit/ha.) with B:C Ratio (1:5.43).

Table.1 Details of pest management modules against mustard aphid, Lipaphis erysimi (Kaltenbach)

\begin{tabular}{|c|c|}
\hline Treatments/Module & Details of the $\operatorname{spray}\left(\operatorname{Spray} 1^{\text {st }}-\right.$ Spray $\left.2^{\text {nd }}\right)$ \\
\hline T1-Module 1 & Azadirachtin 1500 ppm @ 1.5 ml/lit.- acetamiprid 20\% SP @0.037\% \\
\hline T2-Module 2 & Acetamiprid $20 \%$ SP @0.037\%- acetamiprid 20\% SP @0.037\% \\
\hline T3-Module 3 & Azadirachtin 1500 ppm @ 1.5 ml/lit.- imidacloprid 17.8SL @ 20g a.i./ha \\
\hline T4-Module 4 & $\begin{array}{l}\text { Imidacloprid 17.8SL @ 20g a.i./ha (150 ml /ha)-imidacloprid 17.8SL @ } \\
20 \mathrm{~g} \text { a.i./ha(150 } \mathrm{ml} / \mathrm{ha})\end{array}$ \\
\hline T5-Module5 & $\begin{array}{l}\text { Azadirachtin } 1500 \text { ppm @ } 1.5 \text { ml/lit. - azadirachtin } 1500 \text { ppm@ } 1.5 \\
\text { ml/lit. }\end{array}$ \\
\hline T6-Module 6 & $\begin{array}{l}\text { Beauveria bassiana CFU } 1 \times 10^{8} @ 2.0 \mathrm{~kg} / \mathrm{ha}-\text { Beauveria bassiana CFU } \\
1 \times 10^{8} @ 2.0 \mathrm{~kg} / \mathrm{ha} .\end{array}$ \\
\hline T7-Module 7 & Dimethoate30EC @ 300g a.i./ha- dimethoate 30EC @ 300g a.i./ha \\
\hline T8-Control & No insecticide Spray \\
\hline
\end{tabular}


Table.2 Effectiveness of Different modules against mustard aphid Lipaphis erysimi (Kaltenbach) in mustard during Rabi 2016-17

\begin{tabular}{|c|c|c|c|c|c|c|c|c|}
\hline \multirow{3}{*}{ Treatment } & \multirow{3}{*}{ Module } & \multicolumn{7}{|c|}{ Population of Aphids $/ 10 \mathrm{~cm}$ apical shoot } \\
\hline & & \multirow{2}{*}{$\begin{array}{l}\text { Pre- } \\
\text { treatment } \\
1 \mathrm{DBS}\end{array}$} & \multicolumn{3}{|c|}{ First Spray } & \multicolumn{3}{|c|}{ Second Spray } \\
\hline & & & 3DAS & 7DAS & 10DAS & 3DAS & 7DAS & 10DAS \\
\hline T1 & $\begin{array}{l}\text { Module 1. Azadirachtin } 1500 \text { ppm @ } 1.5 \\
\text { ml/lit.- Acetamiprid } 20 \% \text { SP @ } 0.037 \%\end{array}$ & $\begin{array}{l}106.27 \\
(10.33)\end{array}$ & $\begin{array}{l}54.49 \\
(7.41)\end{array}$ & $\begin{array}{l}42.57 \\
(6.56)\end{array}$ & $\begin{array}{l}36.08 \\
(6.05)\end{array}$ & $\begin{array}{l}24.13 \\
(4.96)\end{array}$ & $\begin{array}{r}14.26 \\
(3.84)\end{array}$ & $\begin{array}{c}6.28 \\
(2.60)\end{array}$ \\
\hline T2 & $\begin{array}{l}\text { Module 2. Acetamiprid 20 \% SP @ } \\
0.037 \% \text { - Acetamiprid } 20 \% \text { SP @ 0.037\% }\end{array}$ & $\begin{array}{l}106.77 \\
(10.36)\end{array}$ & $\begin{array}{l}21.39 \\
(4.68)\end{array}$ & $\begin{array}{l}19.80 \\
(4.51)\end{array}$ & $\begin{array}{l}15.88 \\
(4.05)\end{array}$ & $\begin{array}{l}12.88 \\
(3.66)\end{array}$ & $\begin{array}{c}6.17 \\
(2.58)\end{array}$ & $\begin{array}{c}0.88 \\
(1.17)\end{array}$ \\
\hline T3 & $\begin{array}{l}\text { Module 3. Azadirachtin } 1500 \text { ppm @ @ } 1.5 \\
\text { ml/lit.- Imidacloprid 17.8SL@ @20g a.i./ha }\end{array}$ & $\begin{array}{l}107.13 \\
(10.37)\end{array}$ & $\begin{array}{l}54.38 \\
(7.41)\end{array}$ & $\begin{array}{l}43.15 \\
(6.61)\end{array}$ & $\begin{array}{l}36.79 \\
(6.10)\end{array}$ & $\begin{array}{l}26.14 \\
(5.16)\end{array}$ & $\begin{array}{l}13.18 \\
(3.70)\end{array}$ & $\begin{array}{c}5.78 \\
(2.51)\end{array}$ \\
\hline T4 & $\begin{array}{l}\text { Module } 4 \text {. Imidacloprid } 17.8 S L @ 20 \mathrm{~g} \\
\text { a.i./ha( } 150 \mathrm{ml} / \mathrm{ha})- \text { Imidacloprid } 17.8 \mathrm{SL} @ \\
20 \mathrm{~g} \text { a.i./ha( } 150 \mathrm{ml} / \mathrm{ha})(150 \mathrm{ml} / \mathrm{ha})\end{array}$ & $\begin{array}{l}105.82 \\
(10.31)\end{array}$ & $\begin{array}{l}18.64 \\
(4.37)\end{array}$ & $\begin{array}{l}14.91 \\
(3.93)\end{array}$ & $\begin{array}{l}12.02 \\
(3.54)\end{array}$ & $9.44(3.15)$ & $\begin{array}{c}2.79 \\
(1.81)\end{array}$ & $\begin{array}{c}0.00 \\
(0.71)\end{array}$ \\
\hline T5 & $\begin{array}{l}\text { Module 5.Azadirachtin } 1500 \text { ppm @ } 1.5 \\
\text { ml/lit - Azadirachtin } 1500 \text { ppm@ } 1.5 \text { ml/lit }\end{array}$ & $\begin{array}{l}105.98 \\
(10.32)\end{array}$ & $\begin{array}{l}54.07 \\
(7.38)\end{array}$ & $\begin{array}{l}42.57 \\
(6.56)\end{array}$ & $\begin{array}{l}36.70 \\
(6.10)\end{array}$ & $\begin{array}{l}32.97 \\
(5.79)\end{array}$ & $\begin{array}{l}26.76 \\
(5.21)\end{array}$ & $\begin{array}{l}18.28 \\
(4.33)\end{array}$ \\
\hline T6 & $\begin{array}{l}\text { Module 6. Beauveria bassiana CFU } \\
1 \times 108 @ 2.0 \mathrm{~kg} / \mathrm{ha}-\text { Beauveria bassiana CFU } \\
1 \times 108 @ 2.0 \mathrm{~kg} / \mathrm{ha} .\end{array}$ & $\begin{array}{l}108.28 \\
(10.43)\end{array}$ & $\begin{array}{l}35.38 \\
(5.99)\end{array}$ & $\begin{array}{l}34.02 \\
(5.88)\end{array}$ & $\begin{array}{l}28.11 \\
(5.35)\end{array}$ & $\begin{array}{l}23.28 \\
(4.88)\end{array}$ & $\begin{array}{l}16.77 \\
(4.16)\end{array}$ & $\begin{array}{l}10.89 \\
(3.37)\end{array}$ \\
\hline $\mathbf{T} 7$ & $\begin{array}{l}\text { Module 7.Dimethoate 30EC @ 300g a.i./ha- } \\
\text { Dimethoate 30EC @ 300g a.i./ha (1 lit/ha.) }\end{array}$ & $\begin{array}{l}107.34 \\
(10.38)\end{array}$ & $\begin{array}{l}22.74 \\
(4.82)\end{array}$ & $\begin{array}{l}22.51 \\
(4.80)\end{array}$ & $\begin{array}{l}20.28 \\
(4.56)\end{array}$ & $\begin{array}{l}14.12 \\
(3.82)\end{array}$ & $\begin{array}{l}7.29 \\
(2.79)\end{array}$ & $\begin{array}{c}3.16 \\
(1.90)\end{array}$ \\
\hline \multirow[t]{4}{*}{ T8 } & Control & $\begin{array}{l}107.44 \\
(10.39)\end{array}$ & $\begin{array}{l}134.31 \\
(11.61)\end{array}$ & $\begin{array}{r}147.58 \\
(12.17)\end{array}$ & $\begin{array}{l}162.17 \\
(12.75)\end{array}$ & $\begin{array}{l}168.11 \\
(12.98)\end{array}$ & $\begin{array}{l}178.32 \\
(13.37)\end{array}$ & $\begin{array}{l}211.89 \\
(14.57)\end{array}$ \\
\hline & SEm \pm & 0.104 & 0.101 & 0.078 & 0.108 & 0.073 & 0.087 & 0.074 \\
\hline & C.D. at $5 \%$ & 0.315 & 0.307 & 0.236 & 0.327 & 0.221 & 0.264 & 0.225 \\
\hline & $\mathrm{CV}(\%)$ & 1.74 & 2.61 & 2.12 & 3.08 & 2.27 & 3.21 & 3.30 \\
\hline
\end{tabular}

*Figure in parenthesis is square root transformed values, DBS - Day before spray, DAS - Day after spray 
Table.3 Yield and economics of different treatments modules against mustard aphid Lipaphis erysimi (Kaltenbach) in mustard during Rabi 2016-17

\begin{tabular}{|c|c|c|c|c|c|c|c|c|}
\hline $\begin{array}{l}\text { Treatment } \\
\text { /module }\end{array}$ & $\begin{array}{l}\text { Number } \\
\text { of spray }\end{array}$ & $\begin{array}{l}\text { Yield } \\
\text { (q/ha) }\end{array}$ & $\begin{array}{c}\text { Yield } \\
\text { Increased } \\
\text { over control } \\
\text { (q/ha) }\end{array}$ & $\begin{array}{l}\text { Value of } \\
\text { production } \\
\text { (RS) }\end{array}$ & $\begin{array}{c}\text { Value of } \\
\text { saved } \\
\text { yield } \\
\text { (Rs./ha) }\end{array}$ & $\begin{array}{l}\text { Total cost } \\
\text { of } \\
\text { protection } \\
\text { (Rs./ha) }\end{array}$ & $\begin{array}{l}\text { Net income } \\
\text { (Rs./ha) }\end{array}$ & $\begin{array}{c}\text { Cost : } \\
\text { benefit ratio }\end{array}$ \\
\hline $\begin{array}{c}\text { T1- } \\
\text { Module } 1\end{array}$ & 2 & 11.47 & 3.59 & 3500 & 12565 & 2360 & 10205 & $1: 4.32$ \\
\hline $\begin{array}{c}\text { T2 } \\
\text { Module } 2\end{array}$ & 2 & 14.88 & 7.00 & 3500 & 24500 & 3130 & 21370 & $1: 6.83$ \\
\hline $\begin{array}{c}\text { T3 } \\
\text { Module } 3\end{array}$ & 2 & 12.17 & 4.29 & 3500 & 15015 & 2150 & 12865 & $1: 5.98$ \\
\hline $\begin{array}{c}\text { T4 } \\
\text { Module }\end{array}$ & 2 & 16.03 & 8.15 & 3500 & 28525 & 2680 & 25845 & $1: 9.64$ \\
\hline $\begin{array}{c}T 5 \\
\text { Module }\end{array}$ & 2 & 8.97 & 1.09 & 3500 & 3815 & 1120 & 2695 & $1: 2.41$ \\
\hline $\begin{array}{c}\text { T6 } \\
\text { Module }\end{array}$ & 2 & 10.78 & 2.90 & 3500 & 10150 & 1350 & 8800 & $1: 6.52$ \\
\hline $\begin{array}{c}\text { T7 } \\
\text { Module }\end{array}$ & 2 & 13.21 & 5.33 & 3500 & 18655 & 2900 & 15755 & $1: 5.43$ \\
\hline T8 & & 7.88 & & & & & & \\
\hline
\end{tabular}




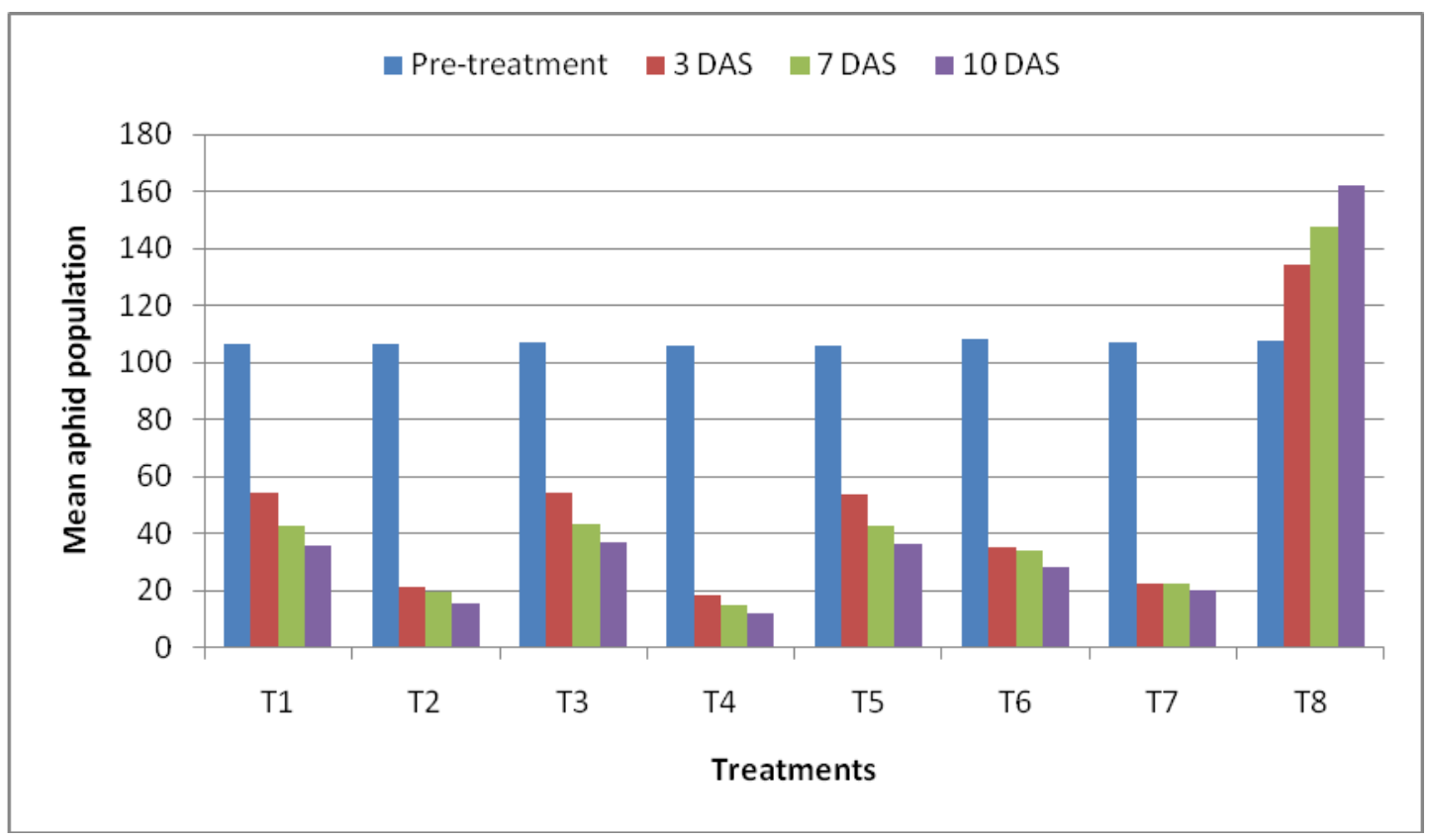

Fig.1 Effect of different treatments modules on the population of mustard aphid ( $1^{\text {st }}$ spray)

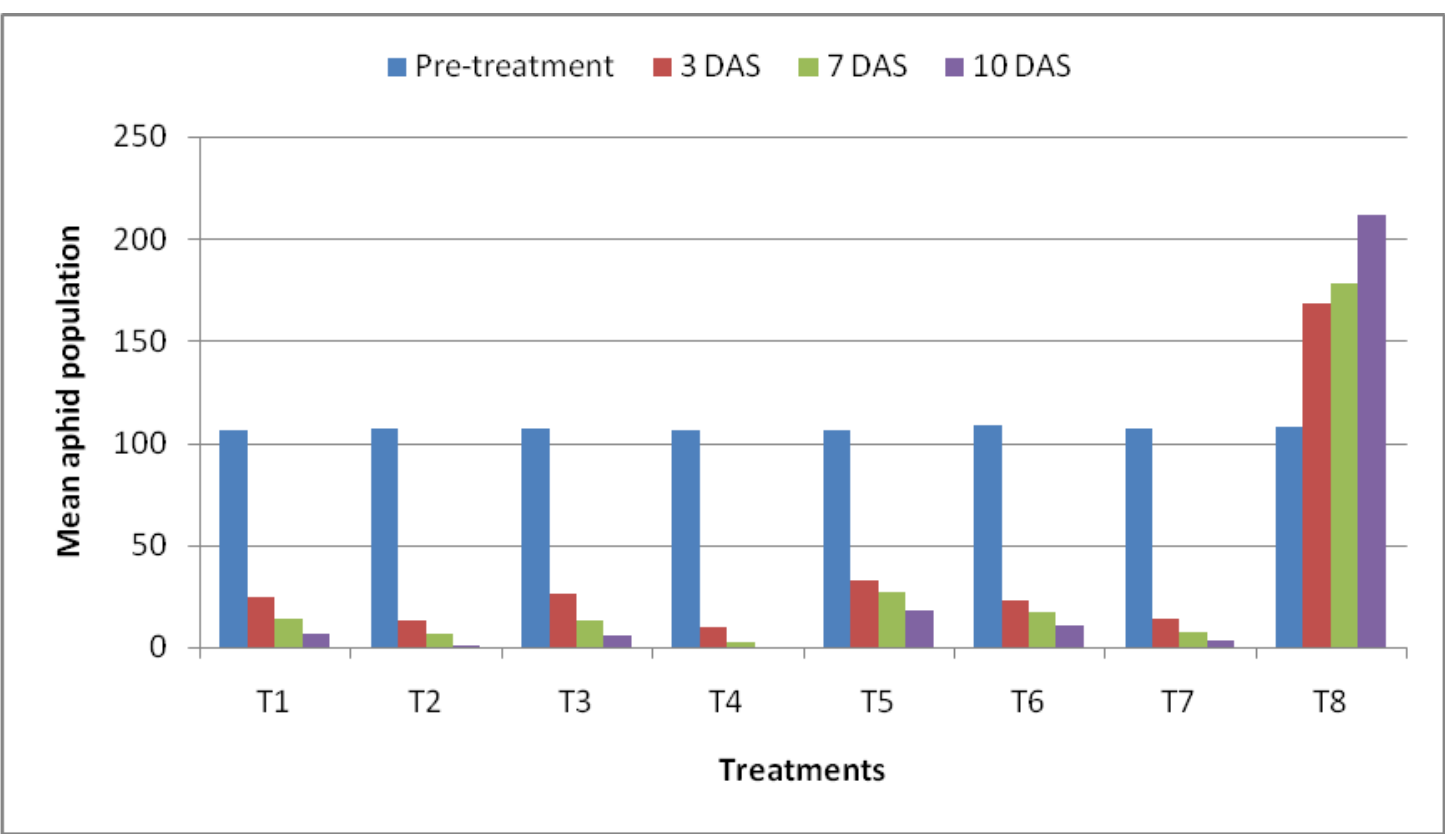

Fig.2 Effect of different treatments modules on the population of mustard aphid ( $2^{\text {nd }}$ spray) 
The lowest benefit cost ratio (1: 2.41) was obtained in Module 5, consisting of azadirachtin 1500 ppm @ $1.5 \mathrm{ml} / \mathrm{lit}$ azadirachtin 1500 ppm @ 1.5 ml/lit. Mandal et al., (2012) also proved that imidacloprid 17.8 SL@ 20g a.i./ha dimethoate 30 EC 300g a.i./ha and thiomethoxam 25 WG @ 25g a.i./ha were effective against mustard aphid and getting maximum yield from imidacloprid 17.8 SL@ 20g a.i./ha and also highest B: C ratio. Meena et al., 2013 also get the maximum yield and benefit cost ratio from Beauveria bassiana $\left(1 \times 10^{8} \mathrm{CFU}\right) @ 2 \mathrm{~kg} / \mathrm{ha}$ and neem seed kernel extracts. Similarly, Sahoo 2012 also observed that acetamiprid 20\% SP @ 0.037\%, imidacloprid 17.8 SL@ $20 \mathrm{~g}$ a.i./ha and dimethoate $30 \mathrm{EC} 300 \mathrm{~g}$ a.i./ha were useful to reduce the population of Liphaphis erysimi and getting maximum yield and benefit cost ratio from dimethoate $30 \mathrm{EC}$ $300 \mathrm{~g}$ a.i./ha which is followed by imidacloprid 17.8 SL @ 20g a.i./ha.

\section{References}

AICRP. 2009. XVI Annual Report of All India Coordinated Research Project on rapeseed-mustard. Directorate of rapeseed-mustard research, Sewar, Bharatpur (Rajasthan).

Anonymous. Annual Progress Report of All India Coordinated Research Project on Rapeseed and Mustard, National Research Centre on Rapeseed Mustard, Sewar, 3213003, Bharatpur, Rajasthan, 2014, 155.

Awasti VB. Introduction to general and applied entomology. Scientific Publisher, Jodhpur, India, 2002, 266271.

Bakhetia DRC and Sekhon BS. Insect pests and their management rapeseed and mustard. Journal of Oilseeds Research. 1989; 6:269-273.

Bapari T, Bhattacharya S, Dhar T. Screening of eco-friendly synthetic insecticides in different spray schedules against Lipaphis erysimi (Kalt.) (Aphididae: Hemiptera). Environment and Ecology. 2008; 26(4): 1945-1950.

Bhati R, Sharma, RC. Efficacy of newer chemicals against mustard aphid. International Quarterly Journal of Biology \& Life Sciences. 2014; 2(4): 1165-1169.

Choudhury S, Pal S. Efficacy of some newer insecticides against mustard aphid, Lipaphis erysimi (Kalt.). New Delhi, India, 2005, 12(2):125-126

Dhaka SS, Singh G, Malik YPS, Kumar A. Efficacy of new insecticides against mustard aphid, Lipaphis erysimi (Kalt.). Journal Oilseeds Research. 2009;26(2):172.

Gazi M, Hossain A, Zahidul M, Islam M, Hossain A., Khalequzzaman M. Effect of Some Insecticides on Mustard Aphid, Lipaphis erysimi (Kaltenbach). Journal of Biological Sciences. 2001; 1(11):1031-1033.

Gour IS, Pareek BL. Field evaluation of insecticides against mustard aphid, Lipaphis erysimi (Kalt.) under semiarid region of Rajasthan. Indian Journal of Plant Protection. 2003; 31(2):25-27.

Islam N, Bhuiyah MIM, Begum A, Karim MA. Field evaluation of foliar insecticides for the control of the mustard aphid, Lipaphis erysimi Kaltenbach. Bangladesh Journal of Zoology. 1990; 18(2): 185-188.

Khedkar AA, Bharpoda TM, Patel MG, Patel CK. Efficacy of different chemical insecticides against mustard aphid, Lipaphis erysimi (Kaltenbach) infesting mustard. International ejournal. 2012; 2277-9663.

Kumar A, Jandial VK, Parihar SBS. Efficacy of different insecticides against mustard aphid, Lipaphis erysimi (Kalt.) on mustard under field 
conditions. International Journal of Agricultural Sciences. 2007; 3(2):9091.

Mandal D, Bhowmik P, Chatterjee ML. Evaluation of new and conventional insecticides for the management of mustard aphid, Lipaphis erysimi Kalt. (Homoptera: Aphididae) on rapeseed (Brassica juncea L.). The Journal of Plant Protection Sciences. 2012; 4(2):37-42.

Meena H, Singh SP, Nagar R. Evaluation of microbial and bio-products for the management of mustard aphid, Lipaphis erysimi (Kalt.). An International Quarterly Journal of Life Science. 2013;8(3):747-750.

Patel, S.R., Awasthi A.K., Tomar R.K.S. Assessment of yield losses in musterd due to mustard aphid under different thermal environments in Eastern Central India. Appl.Ecol.Environ. Resv., 2004.1: 15.

Rana ZA, Shahzad MA, Malik NA, Saleem A. Efficacy of different insecticides and DC-Tron Plus against mustard aphid, Lipaphis erysimi (Kalt). Journal of Agricultural Research (Lahore). 2007; 45(3): 221-224.

Sachan G C and Purwar J P. Integrated insect pest management in rapseed and mustard in; Entomology novel approaches (Eds. Jain PC \& Bhargawa M.L ) New Delhi, India Publishing agency, New Delhi, 2007, pp550.

Sahoo, S. K. (2012) Incidence and management of mustard aphid (Lipaphis erysimi Kaltenbach) in West Bengal, The Journal of Plant Protection Sciences, 4(1): 20-26.

Sharma PK, Kashyap NP. Estimation of losses in three different oil seed Brassica crops due to aphid complex in Himachal Pradesh, India. Journal of Entomology Research. 1998; 22:2225.

Singh PK, Premchand. Yield loss due to the mustard aphid Lipaphis erysimi (Kalt.) in Eastern Bihar Plateau. Journal of Applied Zoological Research. 1995; 6:97-100.

Singh RK, Verma RA. Relative efficacy of certain inscticides against mustard aphid on Indian mustard. Journal of Agriculture Science. 2008; 78(9): 821823.

Sinha RP, Yajdani SS, Kumari K, Hameed SF. Evaluation of different spray schedules for control of mustard aphid. Indian Journal of Entomology. 1997; 59(2):179-186

\section{How to cite this article:}

Jain, D.K., R.K. Gangwar, Hemant Swami and Sumeriya, H.K. 2020. Bioefficacy of IPM Modules for the Management of Aphid, Lipaphis erysimi Kalt. Infesting Mustard in Rajasthan. Int.J.Curr.Microbiol.App.Sci. 9(06): 3613-3623. doi: https://doi.org/10.20546/ijcmas.2020.906.425 